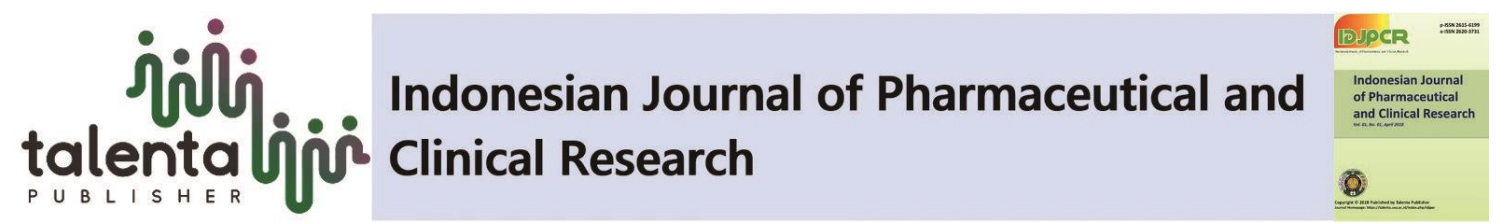

\title{
Hepatoprotective Activity of Curcuma mangga Extract on Paracetamol-Induced Male Mice
}

\author{
Yuandani *, Silvia Mardaliza, Marianne \\ Department of Pharmacology, Faculty of Pharmacy, Universitas Sumatera Utara, Medan 20155, Indonesia
}

\begin{abstract}
This study was carried out to investigate the protective effect of ethanol extract of Curcuma mangga rhizomes on paracetamol-induced hepatotoxicity. High dose of paracetamol $(1.35 \mathrm{~g} / \mathrm{kg} \mathrm{bw})$ was used to induce hepatic necrosis of mice liver. The male mice received ethanol extract of $C$. mangga rhizomes $(100,200$ and $400 \mathrm{mg} / \mathrm{kg}$ BW) for 7 days. The hepatoprotective actvity of extract was compared to normal, positive (curcuma) and negative control. The liver function was evaluated by measuring the biochemistry parameters which include alanine aminotransferase (ALT) and aspartate aminotransferase (AST). In addition, histophatological study on hepatic tissue section was also carried out. The C. mangga extract displayed hepatoprotective effect except at dose of $100 \mathrm{mg} / \mathrm{kg}$ bw. The increasing of serum levels of AST and ALT were inhibited after treatment with ethanol extract at doses of 200 and $400 \mathrm{mg} / \mathrm{kb}$ bw which was comparable with normal and Curcuma ${ }^{\circledR}$ as positive control ( $\left.p>0.05\right)$. In addition, histological assessment of hepatic tissue demonstrated no liver damage, specially at dose of $400 \mathrm{mg} / \mathrm{kb} \mathrm{BW}$. The result indicate that ethanol extract of $C$. mangga rhizomes has hepatoprotective effect, especially at doses of 200 and $400 \mathrm{mg} / \mathrm{kg}$ bw .
\end{abstract}

Keywords: $C$. mangga, rhizomes, biochemistry parameters, histopathology

\begin{abstract}
Abstrak. Penelitian ini dilakukan bertujuan untuk mengetahui efek perlindungan dari ekstrak etanol rimpang Curcuma mangga pada hepatotoksisitas yang diinduksi parasetamol. Parasetamol dosis tinggi $(1,35 \mathrm{~g} / \mathrm{kgbb})$ digunakan untuk menginduksi nekrosis hati pada tikus. Tikus jantan diberikan ekstrak etanol rimpang C. mangga (100, 200 dan $400 \mathrm{mg} / \mathrm{kg}$ bb) selama 7 hari. Aktivitas hepatoprotektif ekstrak dibandingkan dengan kontrol normal, positif (curcuma) dan negatif. Fungsi hati dievaluasi dengan mengukur parameter biokimia yaitu alanine aminotransferase (ALT) dan aspartate aminotransferase (AST). Selain itu, pemeriksaan histopatologis pada bagian jaringan hati juga dilakukan. Ekstrak C. mangga menunjukkan efek hepatoprotektif kecuali pada dosis $100 \mathrm{mg} / \mathrm{kg} \mathrm{bb}$. Peningkatan kadar serum AST dan ALT dihambat setelah pemberian ekstrak etanol pada dosis 200 dan $400 \mathrm{mg} / \mathrm{kg} b \mathrm{~b}$ yang dibandingkan dengan kontrol normal dan Curcuma ${ }^{\circledR}$ sebagai kontrol positif $(p>0,05)$. Selain itu, penilaian histologis jaringan hati menunjukkan tidak ada kerusakan hati, khususnya pada dosis $400 \mathrm{mg} / \mathrm{kg} \mathrm{bb}$. Hasil penelitian menunjukkan bahwa ekstrak etanol rimpang C. mangga memiliki efek hepatoprotektif, terutama pada dosis 200 dan $400 \mathrm{mg} / \mathrm{kg} \mathrm{bb}$.
\end{abstract}

Kata kunci: C. mangga, rimpang, parameter biokimia, histopatologi

Received 30 August 2018 | Revised 2 October 2018 | Accepted 26 November 2018

*Corresponding author at: Universitas Sumatera Utara, Medan, Indonesia

E-mail address: yuandani@usu.ac.id

Copyright (C) 2018 Published by Talenta Publisher, Print ISSN : 2615-6199, Online ISSN : 2620-3731

Journal Homepage: https://talenta.usu.ac.id/index.php/idjpcr 


\section{Introduction}

Nowadays, utilization of hepatoprotective drugs to treat various hepatic diseases has increased. Hepatoprotective agents are normally used in patients with elevated biochemistry parameters such as alanin aminotransferase (ALT) and aspartat aminotranferase (AST) [1]. There are some conditions which may arise the AST and ALT levels, which include liver inflammation or drug-induced liver disease. Several drugs are widely known to induce liver damage. These include paracetamol, isoniazid, rifampin, metothrexate and phenitoin [2]. Paracetamol (acetaminophen) is considered untoxic at therapeutic doses and short term use. Paracetamol undergo metabolism by the enzymes cytochrome P450 to toxic metabolit, known as N-acetyl-p-benzoquinone imine (NAPQI) [3].

Hepatoprotective drugs have been studied for its possibility to treat virus-induced chronic hepatitis [4]. Discovery and development of hepatoprotective drugs has gained momentum in recent years. Medicinal plants preserve a source of hepatoprotective drugs [1].

Curcuma mangga rhizome was found to be rich in various bioactive compounds. These include secondary metabolite compounds with medicinal importance such as curcumin, $\beta$-sitosterol, bisdemethoxycurcumin and demethoxycurcumin [5-6]. This plant has long been used in traditional medicine for the treatment of various diseases such as fever, stomach disorders and cancer [6]. Previous study has showed the immunomodulatory properties of C. mangga [7]. The anticancer, anti-inflammatory, antifungal and nitric oxide inhibitory activities of $C$. mangga have also been reported [8-11]. Safety assessment which revealed that it was untoxic in show short-term treatment has emphasized to evaluate its hepatoprotective activity [12]. The current study was carried out to evaluate the effects of C. mangga extract on its ability to prevent hepatic necrosis which induced by high dose of paracetamol.

\section{Materials and Methods}

\subsection{Chemicals and reagents}

There were several chemicals used in this study, natrium carboxylmethlcellulose (Na CMC), ethanol (SmartLab, Indonesia) (Sigma, USA), and Curcuma ${ }^{\circledR}$ (Soho, Indonesia). A light microscope (Boeco, Germany) and rotary evaporator (Heidolph, Germany) were also used in this study.

\subsection{Plant materials}

The $C$. mangga rhizomes were obtained from Deli Serdang, Indonesia. The plant was identified by Herbarium Medanese (MEDA) Universitas Sumatera Utara, Indonesia. 


\subsection{Extraction procedure}

The extract was prepared by maceration method. Briefly, the C. mangga rhizomes materials were cut, dried and ground. Then $500 \mathrm{~g}$ of sample was soaked in ethanol at ratio 1:10, then filtered after 3 days. Again, the residue was soaked and filtered after another 3 days. Thereafter, the combined filtrates were evaporated to remove the solvent and to obtain ethanol extract of C. mangga.

\subsection{Experimental Procedure}

The protective effect on liver was evaluated followed a modified previous method [13]. The mice received C. mangga extract at doses of 100,200 and $400 \mathrm{mg} / \mathrm{kg}$ bw for 7 days by oral route. Curcuma ${ }^{\circledR}$ (54 mg/kg bw) was used as positive control. The negative control and normal group were treated with $\mathrm{Na}$ CMC $0.5 \%$ as vehicle. On day 7, except normal group, all mice were induced by high dose of paracetamol $(1,35 \mathrm{~g} / \mathrm{kg} \mathrm{bw})$. After 24 hours, the mice were sacrified and blood were collected for biochemical parameters examination. Histological assesment was performed on hepatic tissue section. The use of mice was approved by the Animal Research Ethics Committees of Universitas Sumatera Utara (approval number 098/KEPH-FMIPA/2017).

\subsection{Biochemical Parameters Evaluation}

The blood were centrifuged for $20 \mathrm{~min}$ at $3000 \mathrm{rpm}$. Thereafter, the serum was separated to determine the levels of alanin aminotransferase (ALT) and aspartate aminotranferase (AST).

\subsection{Histological Assesment}

Microscopic examination on tissue section was conducted by slicing with a microtome after the liver has been embbeded in paraffin. Observation was performed using a light microscope.

\subsection{Statistical analysis}

The data were analyzed using SPSS 17.0 using ANOVA a one-way ANOVA. Then, followed by Tukey post hoc test. The different significance was ANOVA at $\mathrm{P}<0.05$.

\section{Results And Discussion}

\subsection{Biochemical Parameters}

The C. mangga extract at dose of $100 \mathrm{mg} / \mathrm{kg}$ BW still showed comparable ALT and AST levels to negative control $(\mathrm{P}>0.05)$ as shown in Table 1 . The extract started to prevent paracetamol-induced hepatic necrosis at dose of 200 and $400 \mathrm{mg} / \mathrm{kg}$ bw which indicated by normal values of ALT and AST when compared to negative control $(\mathrm{P}<0.05)$. The high dose of acetaminophen induced liver damage due to the decreasing store of Glutathione S-transferase pi 1(GSTP1). This condition causes a reactive metabolite NAPQI begins to react to hepatocytes and induced hepatic necrosis [2]. The extract of $C$. mangga was 
able to prevent induced liver damage by preventing increase level of ALT and AST after treatment with large dose of paracetamol. The levels of ALT and AST are normally used to monitor liver function because they are released by hepatic tissue damage [14]. The C. mangga extract at dose of 200 and 400 $\mathrm{mg} / \mathrm{kg}$ bw demonstrated comparable hepatoprotective activity with normal and positive control $(\mathrm{P}>0.05)$.

Table 1. Effect of extract on ALT and AST levels after treatment with paracetamol (Mean \pm SD)

\begin{tabular}{clcc}
\hline No. & \multicolumn{1}{c}{ Groups } & ALT (IU/L) & AST (IU/L) \\
\hline 1. & $\begin{array}{l}\text { Normal (Na-CMC 0,5\% without } \\
\text { paracetamol) }\end{array}$ & $111.75 \pm 11.84$ & $245.00 \pm 30.04$ \\
2. $\begin{array}{l}\text { Negative control (Na-CMC 0,5\% } \\
\text { with paracetamol) }\end{array}$ & $697.75 \pm 11.14^{*}$ & $813.50 \pm 41.58^{*}$ \\
3. $\quad \begin{array}{l}\text { Positive control (Curcuma } 58 \mathrm{mg} / \mathrm{kg} \\
\text { bw) }\end{array}$ & $171.75 \pm 76.03^{\mathrm{a}}$ & $288.75 \pm 59.67^{\mathrm{a}}$ \\
4. $\quad \begin{array}{l}\text { C. mangga extract } 100 \mathrm{mg} / \mathrm{kg} \text { bw } \\
\text { 5. }\end{array}$ & $675.25 \pm 256.51^{\mathrm{b}, *}$ & $785.25 \pm 44.39^{\mathrm{b}, *}$ \\
6. mangga extract $200 \mathrm{mg} / \mathrm{kg}$ bw & $212.25 \pm 10.53^{\mathrm{a}, *}$ & $306.43 \pm 12.19^{\mathrm{a}}$ \\
& C. mangga extract $400 \mathrm{mg} / \mathrm{kg} \mathrm{bw}$ & $187.75 \pm 11.21^{\mathrm{a}, *}$ & $266.18 \pm 10.12^{\mathrm{a}}$
\end{tabular}

$\mathrm{a}=$ significantly different with negative control $(\mathrm{p}<0.05)$

$\mathrm{b}=$ significantly different with positive control $(\mathrm{p}<0.05)$

$*=$ significantly different with normal $(\mathrm{p}<0.05)$

\subsection{Histological Assessment}

Figure 1 shows necrotic cells after treatment by large dose of paracetamol. Microsopic examination on hepatic tissue showed no hepatic necrosis after treatment by C. mangga extract at dose of 200 and 400 $\mathrm{mg} / \mathrm{kg}$ bw. The result was in agreement with the biochemistry examinations, the $C$. mangga extract prevented the necrotic hepatocytes in liver. The curcuminoid content which include curcumin, demethoxycurcumin and bisdemethoxycurcumin in C. mangga rhizomes might play important role in inhibiting hepatic necrosis induced by paracetamol [5]. 

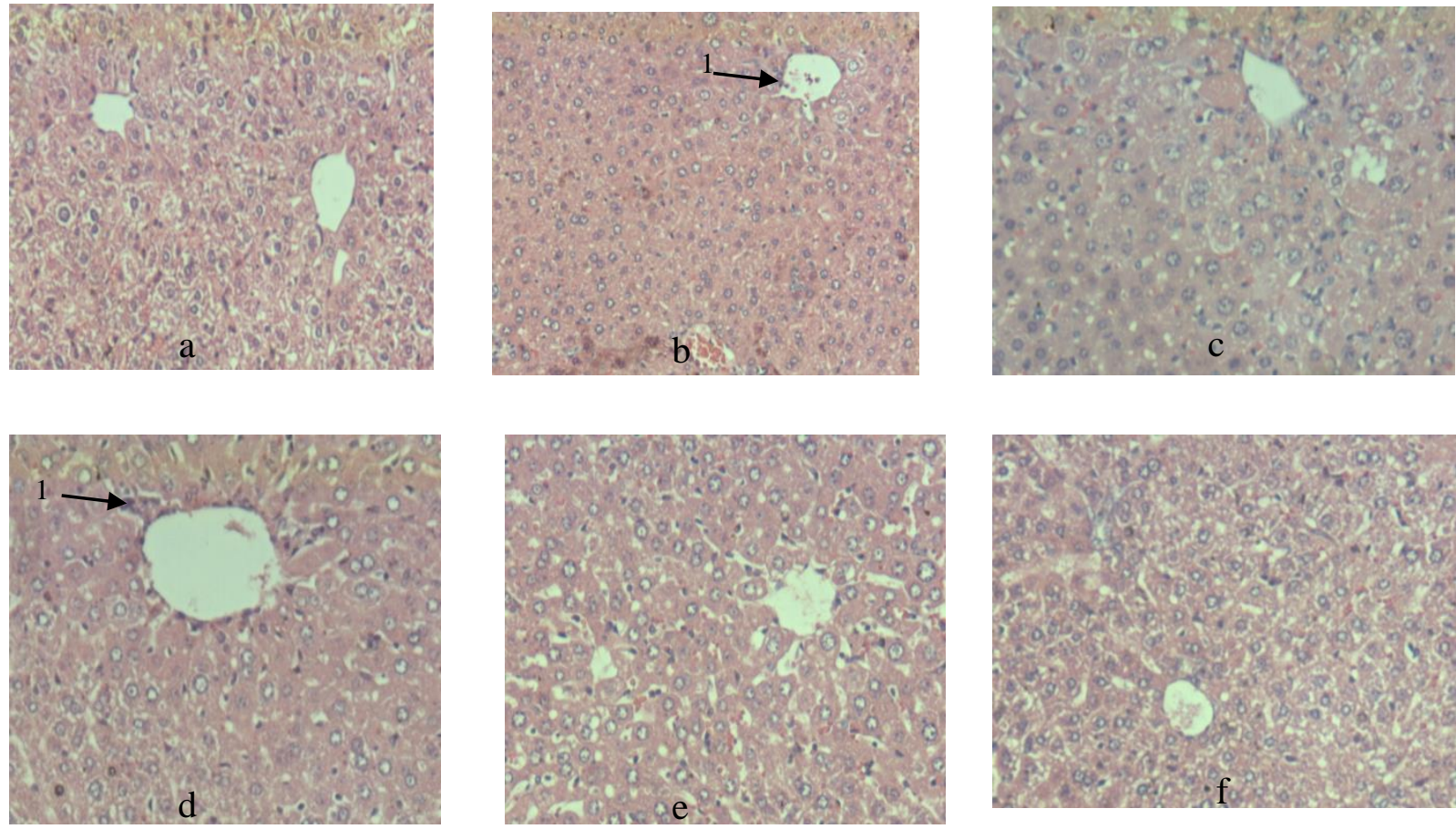

Figure.1. Microscopic examination $(10 \times 10)$. (a) Liver of normal control rat; (b) liver of negative control rat; (c) Liver of positive control rat; (d) Liver after treatment with C. mangga extract at $100 \mathrm{mg} / \mathrm{kg}$; (e) Liver after treatment with $C$. mangga extract at $200 \mathrm{mg} / \mathrm{kg}$; (f) Liver after treatment with $C$. mangga extract at $400 \mathrm{mg} / \mathrm{kg}$; (1) necrotic hepatocyte

\section{Conclusion}

The ethanol extract of $C$. mangga rhizomes displayed hepatoprotective activity at dose of 200 and 400 $\mathrm{mg} / \mathrm{kg}$ bw. The extract prevented increase in serum ALT and AST after treatment with high dose of paracetamol. The result was supported by no necrotic hepatocyte observed within the liver after treatment by extract. However, further studies are necessary to elucidate the hepatoprotective mechanism of $C$. mangga rhizomes.

\section{ACKNOWLEDGEMENT}

Nil 


\section{REFERENCES}

[1] S.D. Roy, S. Das, D. Shil, and K.N. Dutaa, "Herbal hepatoprotective agents: a review", World J Pharm Res, vol. vol.1, no. 2, pp. 87-99. 2012.

[2] J. T. DiPiro, R. L. Talbert, G. C. Yee, G. R. Matzke, B. G. Wells, L. M. Posey, D. S. Streetman, and D.-A. D. Streetman, "Book Review: Pharmacotherapy: A Pathophysiologic Approach, 7th Edition," Annals of Pharmacotherapy, vol. 43, no. 2, pp. 395-395, Feb. 2009.

[3] R. B. Pingili, A. K. Pawar, and S. R. Challa, "Systemic exposure of Paracetamol (acetaminophen) was enhanced by quercetin and chrysin co-administration in Wistar rats andin vitromodel: risk of liver toxicity," Drug Development and Industrial Pharmacy, vol. 41, no. 11, pp. 1793-1800, Feb. 2015.

[4] T. Okamoto, K. Kajino, and O. Hino, "Hepatoprotective Drugs for the Treatment of Virus-Induced Chronic Hepatitis: From Hypercarcinogenic State to Hypocarcinogenic State.," The Japanese Journal of Pharmacology, vol. 87, no. 3, pp. 177-180, 2001

[5] S. N. A. Malek, G. S. Lee, S. L. Hong, H. Yaacob, N. A. Wahab, J.-F. Faizal Weber, and S. A. A. Shah, "Phytochemical and Cytotoxic Investigations of Curcuma mangga Rhizomes," Molecules, vol. 16, no. 6, pp. 4539-4548, May 2011.

[6] F. Abas, N. H. Lajis, K. Shaari, D. A. Israf, J. Stanslas, U. K. Yusuf, and S. M. Raof, "A Labdane Diterpene Glucoside from the Rhizomes ofCurcumamangga," Journal of Natural Products, vol. 68, no. 7, pp. 1090-1093, Jul. 2005.

[7] Y. Yuandani and E. Suwarso, "Immunomodulatory effects of ethanol extract of curcuma mangga rhizomes in mice," Asian Journal of Pharmaceutical and Clinical Research, vol. 10, no. 9, p. 148, Sep. 2017.

[8] P. Ruangsang, S. Tewtrakul, and W. Reanmongkol, "Evaluation of the analgesic and antiinflammatory activities of Curcuma mangga Val and Zijp rhizomes," Journal of Natural Medicines, vol. 64, no. 1, pp. 36-41, Oct. 2009.

[9] R. Tjandrawinata, A. H. Karsono, and O. M. Tandrasasmita, "Molecular effects of bioactive fraction of Curcuma mangga (DLBS4847) as a downregulator of 5a-reductase activity pathways in prostatic epithelial cells," Cancer Management and Research, p. 267, Jun. 2014.

[10] F. Abas, N. H. Lajis, D. A. Israf, S. Khozirah, and Y. Umi Kalsom, "Antioxidant and nitric oxide inhibition activities of selected Malay traditional vegetables," Food Chemistry, vol. 95, no. 4, pp. 566-573, Apr. 2006.

[11] I. bin Jantan, M. S. M. Yassin, C. B. Chin, L. L. Chen, and N. L. Sim, "Antifungal Activity of the Essential Oils of Nine Zingiberaceae Species," Pharmaceutical Biology, vol. 41, no. 5, pp. 392397, Jan. 2003.

[12] Yuandani and E. Suwarso, "Acute Toxicity Evaluation Of Ethanol Extract Of Curcuma Mangga Rhizome," Asian Journal of Pharmaceutical and Clinical Research, vol. 10, no. 1, p. 383, Jan. 2016.

[13] M. T. Olaleye, A. E. Amobonye, K. Komolafe, and A. C. Akinmoladun, "Protective effects of Parinari curatellifolia flavonoids against acetaminophen-induced hepatic necrosis in rats," Saudi Journal of Biological Sciences, vol. 21, no. 5, pp. 486-492, Nov. 2014.

[14] L.K. Yin, and K.S. Tong, "Elevated alt and ast in an asymptomatic person What the primary care doctor should do?" Malays Fam Physician,vol. 4 no.2.2009 